feet from the floor. The action of this organ is electrical, that is, there is no mechanical communication between the performer at the key-board roo feet distant and the organ pallets which admit the wind to the pipes, save a small rope of $6 \mathrm{I}$ insulated copper wires-one wire for each nole of the five octaves. The various stops of this distant organ are likewise controlled without mechanism - a series of vacuum tubes alone extending from the registers at the great organ to the sliders of the echo organ--which are thus brought on or off at the will of the performer by a silent action-at once accurate and instantaneous in its manipulation. The effect of this eche organ, is that of a large organ heard at a great distance. Without the aid of the electric action, and vacuum pressure, such an organ could not have been designed. Mechanical action would never have successfully developed such effects at such an extended distance.

The same vacuum system is also applied to the various pneumatic lever arrangements interposed between the keys at the consol and the wind-valves at the soundboards to relieve the performer from any undue mechanical pressure that might detract from the promptness of repetition and delicacy of touch of the key action, the key boards being thus rendered as light as that of a grand pianoforte. Such results cannot be obtained so efficiently by the employment of compressed air for a pneumatic power action; compressed air will always prove to be more or less sluggish, a "creeping on" and "creeping off" movement being the result, besides a limit to the aguregate of the instantaneous power that is at command.

The pneumatic drawstop action of the St. George's Hall organ, Liverpool, is a fair illustration of the defects of the compressed air system. In the Primrose Hill organ upwards of forty registers can be simultaneously drawn on or shut off as easily and with the same precision as though only a single stop were drawn. The consol or keyboards of this organ, as will be seen by the engraving, are reversed, that is, the performer faces the audience, the organ being behind, and the echo organ opposite him. The lowest keyboard manual is the "great organ;" the next, or second from the bottom, the "choir organ ;" the third in :he series the "swell organ;" and the fourth, or upper row of keys, the "solo organ." By a simple mechanical arrangement this fourth keyboard is also used for the electric "echo organ," and also for the carillon, or "bell" organ, otherwise it would have been necessary to have introduced a fifth set of keys, an arrangement at all times objectionable from the increased complications imposed upon the performer. The touch of the carillon organ on the fourth row of keys is expressive like that of the pianoforte key, and gradations of tone and distance are therefore capable of being expressed upon the bells.

In this organ the French ventil system of shutting off or bringing on the wind to a complete family or group of stops by the depression of a pedal has not been adopted, such a system being found inadequate to effect rapidly the almost endless combinations that such a large instrument has at command, the pneumatic combination foot pedals and finger buttons at the keyboards being introduced as a more convenient form of manipulating the registers.

The wind supply of this gigantic organ is furnished from four large reservoirs in the basement, which again supply seventeen reservoirs in connection with the various scund-boards of the organ; the vertical feeders for producing the wind to these reservoirs, as well as for creating the vacuum pressure, are set in motion by an eleven horsepower steam-engine. The wind supply is so ample, that with the power of the full organ it is impossible to exhaust or create unsteadiness in the wind; few organs are properly constructed in this important respect. An ingenimis automatic lever engine for regulating the motion and the supply of wind from the vertical feeders into the reservoirs according to the demand of the organ, is placed between the steam-engine and the wind reservoirs, so that the regulation of the wind supply is independent of the speed of the engine, which remains constant. This instrument, which occupied three years in its construction, and was opened in January, 1876 , has been erected under the personal supervision of Mr. W. T. Best, of Live rpool, by the eminent organ builders Messrs. Bryceson Brothers, and Morten, of London, for Mr. Nath. J. Holmes, and is erected in the large music-room at the Hall, Primrose Hill Road, built expressly to receive it. The instrument, which stands 50 feet high, 30 feet broad, and 30 feet deep, suffered severe injury from the effects of concussion, in common with the building in which it is erected, at the time of the disastrous explosion of gunpowder on the Regent's Park Canal, near Primrose Hill.

\section{PALAEONTOLOGY AND THE DOCTRINE OF DESCENT}

"THE great biological question of the day is the problem of evolution; but geologists, as Kant says, are the archæologists of nature, and the sole direct and irrefragable evidence of the method whereby living things have become what they are is to be sought among fossil remains" Such were the words spoken by Prof. Huxley on a recent occasion, when receiving from the hands of the president of the Geological Saciety the Wollaston medal ; and the assembled geologists, calling to mind his masterly review of the whole question in his address to them in 1870 , rejoiced to hear their formex president expressing the hope that much of his future labour would be concentrated on this all-important palæontological problem.

The discoveries of such abundant mammalian remains in the Tertiary deposits of the Western territories of America have added much valuable material to that already obtained from the Paris basin, the Sivalik Hills, Pikermi, and many other districts; and we may look forward with confidence to the labours of vertebrate palæontologists for bringing to light many interesting relations between the members of the existing fauna and their ancestral representatives in the later geological periods.

In the meanwhile it may not be uninteresting to point out that among the invertebrata similar evidences of the transitions between life-forms which at first sight appear to ronstitute perfectly distinct groups, are constantly being detected by palæontologists. No opportunity for doing this more effectively could possibly be desired than that which is afforded by the publication of a most suggestive and valuable monograph by the distinguished palæontologist of Vienna, Dr. Neumayr, in conjunction with M. Paul of the Austrian Geological Survey, a work which has just apppeared in the seventh volume of the Abhandlungen der $k$. k. geologischen Reichsanstalt. The title of this memoir is "Die Congerien- und Paludinen-schichten Slavoniens und deren Faunen; ein Beitrag zur Descendenz-Theorie;" and its authors have earned the thanks alike of geologists and biologists, for the important evidence on the great question of evolution which has been the fruit of their patient researches.

The geological formation which has afforded the evidence in question is the grand series of lacustrine beds forming the highest portion of the magnificently developed Tertiaries of Eastern Europe, and which constitute the approximate equivalent, in all probability, of our Pliocene ; and it is a district on the southern limits of the Austrian Empire, the border-land of that area to which the attention of all Europe has been so painfully dra wn for many months past, that has furnished the valuable sections of this formation and the abundant fossil remains, the 
discussion of which is the object of the memoir we are noticing: On the northern bank of the Save there rises from the "diluvium" of the vast Hungarian plains an "island" composed of various crystalline, Triassic, and Tertiary rocks, and on the southern side of this tract of older deposits and upheaved along its flanks, between the towns of Alt Gradiska and Turkish Brod, stretches a vast mass of strata, constituting probably the most magnificent representative of the latest stage of the Tertiary period which geologists have as yet had the good fortune to discover.

The strata in question consist of sands and clays, with numerous beds of lignite, and it is to the value of the latter as fuel that we are indebted for those excavations which have afforded such excellent opportunities for studying the successive series of faunas of the formation. The whole of the beds appear to be of lacustrine origin, and have been accumulated, doubtless through the longcontinued subsidence of the area, to the enormous thickness of about 2,000 feet ; the lower division of the strata known as the "Congerien-Schichten," appears to have been formed under brackish-water conditions, but their upper and by far their thickest portion was certainly accumulated in fresh water. This upper fresh-water series, the "Paludinen-Schichten," is divided by our authors into three principal groups, comprising eight zones, each of which exhibits a well-marked and characteristic fauna.

The group of shells which affords the most interesting evidence of the origin of new forms through descent with modification is that of the genus Vivipara or Paludina, which occurs in prodigious abundance throughout the whole series of fresh water strata. We shall not, of course, attempt in this place to enter into any details concerning the forty distinct forms of this genus (Dr. Neumayr very properly hesitates to call them all species) which are named and described in this monograph, and between which, as the authors show, so many connecting links, clearly illustrating the mode of derivation of the newer from the older types, have been detected. On the minds of those who carefully examine the admirably engraved figures given in the plates accompanying this valuable memoir, or still better the very large series of specimens from among which the subjects of these figures are selected, and which are now in the museum of the Reichsanstalt of Vienna, but little doubt will, we suspect, remain that the authors have fully made out their case, and have demonstrated that, beyond all controversy, the species with highly complicated ornamentation were variously derived by descent--the lines of which are in most cases perfectly clear and obvious-from the simple and unornamented Vivipara achatinoides of the Congerien-Schichten. It is interesting to notice that a large portion of these unquestionably derived forms depart so widely from the type of the genus Vivipara that they have been separated on so high an authority as that of Sandberger, as a new genus, under the name of Tulotoma. And hence we are led to the conclusion that a vast number of forms, certainly exhibiting specific distinctions, and, according to some naturalists, differences even entitled to be regarcied of generic value, have all a common ancestry.

The vast Tertiary lake-basins of Eastern Europe, in which similar conditions were maintained during such an enormous period, and in which such an unbroken sequence of deposits was accumulated, offer, of course, a particularly favourable opportunity for investigating the relations existing between successive life forms. The disturbing elements, arising from rapid variations in physical conditions attended with the circumstance of the immigration of forms from other areas, and the consequent retreat of the older fauna, the evidence of which is so constantly detected in the case of geological formations of marine origin, are here to a very great extent eliminated; and hence we are able to trace with marvellous precision the exact pedigree of an immense number of diverse forms.

We may, however, be permitted to add that much of the failure in recognising the undoubted ancestral relationships which exist between many marine invertebrate fossil forms, appears to arise either from prejudice on the part of the observers, or from that unfortunate divorce between the work of the physical geologist and the palæontologist, which, in this country at least, tends to confine the former entirely to the field, and the latter as absolutely to the museum. In no way can the admirable results which may be expected to ensue from the combined study of the physical and palæontological characteristics of a formation be better exemplified than by an appeal to the publications of the Geological Reichsanstalt of Vienna. In the same volume of the Abhandlungen, which contains the valuable memoir to which we have alluded in the former part of this article, is published a second instalment of Dr. E. Mojsisovics' splendid monograph, "Die Mollusken-Faunen der Zlambach und Halls:ä:terSchichten," in which the wonderfully-varied molluscan forms of the Alpine Trias are so admirably described, their derivation traced, and their relations to the Palæszoic and Mesozoic types clearly indicated. While the study of such exceptionally well-preserved faunas as those we have alluded to cannot but impress us with that incompleteness which is undoubtedly the usual characteristic of "the geological record," it nevertheless leads us to entertain the hope, and even to express the certainty, that in the hands of the palæontologist lies the key to that mystery which at present envelopes the laws that have governed the appearance of the successive forms of life.

J. W. JUDD

PRIZES OFFERED BY THE DUTCH SOCIETY OF SCIENCES

THE following subjects for prizes have been proposed by the Dutch Society of Sciences, Haarlem.

1. To make a complete experimental study of the question whether a Daniell element can decompose water, and to sulmit to a critical examination the theories according to which it does or does not possess this power.

2. What are the meteorological and magnetic phenomena which there are sufficient reasons for believing to be connected with sun-spots?

3 It seems to result from certain experiments of $M$. Bunsen (Ann. der Chem. und Fharm. Ixxxv. p. 137, et. seq., I863), that when mixtures of hydrogen and carbonic oxide are inflamed in a eudiometer with a quantity of oxygen insufficient for complete combustion, there always remains a part of the two combustible gases, and that the quantities of water and of carbonic dioxide which are formed have the relation to each other of simple multiples of their molecular weights. The same will hold good for the quantities of carbonic monuxide and carbonic dioxide which are generated by the combustion of cyanogen by means of a limited quantity of oxygen. The Society requires that these experiments be repeated on a more extended scale, with gaseous mixtures of very diverse composition, and by varying considerably the proportions of the constituents.

4. The researches of $\mathrm{Mr}$. Lockyer concerning the difference of the spectral lines which calcium gives by means of electricity at different temperatures, have excited in a high degree the interest of the Society which requires that these important researches be extended to other elements.

5. Give a critical résumé of the observations and experiments concerning the existence of Bacteria in the contagious diseases of man, followed by original resea ches on the same question, studied in one or more of these diseases.

6 . The society requires a simple instrument by which temperatures above $350^{\circ} \mathrm{C}$. may be measured in degrees of the airthermometer.

7. Make researches on the influence which the different colours of the spectrum exercise on the life of the lower animals. 